\title{
Cropping systems sustainability: Inoculation and fertilisation effect on sulla performances in a new cultivation area
}

\author{
Leonardo Sulas, ${ }^{1}$ Giovanna Piluzza, ${ }^{1}$ Mauro Salis, ${ }^{1}$ Paola A. Deligios, ${ }^{2}$ Luigi Ledda, ${ }^{2}$ \\ Simone Canu ${ }^{3}$
}

\begin{abstract}
${ }^{1}$ Institute for the Animal Production System in Mediterranean Environment, National Research Council, Sassari; ${ }^{2}$ Department of Agriculture Sciences, University of Sassari; ${ }^{3}$ Institute for Biomolecular Chemistry, National Research Council, Sassari, Italy
\end{abstract}

\begin{abstract}
To assess the feasibility of the sulla [Sulla coronaria (L.) Medik] forage legume in a new agroecosystem, its host-specific symbiotic interaction needs to be taken into account. This study aimed to investigate the effects of inoculation and nitrogen $(\mathrm{N})$ fertiliser on productive performances and $\mathrm{N}$-fixation ability of sulla established in a new habitat within a Mediterranean agropastoral area. Sulla plants, previously inoculated (with peat-based, liquid inoculants, and using soil from an existing sulla field) and unfertilised or $\mathrm{N}$ fertilised were evaluated in Sardinia (Italy). During 2013-2014, sulla plants were sampled at four growing stages, from vegetative stage to seed set, and shoot length, shoot dry matter (DM) yield and $\mathrm{N}$ content were monitored. Moreover, atom $\%{ }^{15} \mathrm{~N}$ isotopic excess, proportion of $\mathrm{N}$ derived from the atmosphere and fixed $\mathrm{N}$ of sulla shoots were quantified. Inoculation and $\mathrm{N}$ fertilisation both affected growth, DM and $\mathrm{N}$ yields, and N-fixation of sulla. Compared to the best inoculated treatment, the DM yield and fixed $\mathrm{N}$ of the control only represent-
\end{abstract}

Correspondence: Leonardo Sulas, Institute for the Animal Production System in Mediterranean Environment, National Research Council, Traversa La Crucca 3, località Baldinca 07100 (SS), Italy.

Tel: +39.079.2841606 - Fax: +39.079.2841699.

E-mail: 1.sulas@cspm.ss.cnr.it

Key words: Fertilisation; Inoculation; Legume benefits; N-fixation; Sulla; Symbiosis.

Acknowledgements: the authors wish to thank Dr. Pietro Meloni for hosting the experimental trial in his family farm, and Ms. Maria Maddalena Sassu, Mr. Anton Pietro Stangoni and Dr. Giuseppe Campesi at CNR ISPAAM for their valuable technical assistance in the field and laboratory.

Received for publication: 8 February 2017.

Revision received: 21 April 2017.

Accepted for publication: 22 April 2017.

(C) Copyright L. Sulas et al., 2017

Licensee PAGEPress, Italy

Italian Journal of Agronomy 2017; 12:938

doi:10.4081/ija.2017.938

This article is distributed under the terms of the Creative Commons Attribution Noncommercial License (by-nc 4.0) which permits any noncommercial use, distribution, and reproduction in any medium, provided the original author(s) and source are credited. ed 10 to $22 \%$ and 2 to $11 \%$, respectively. Nitrogen fertilisation caused temporary decreases in the $\mathrm{N}$ fixing ability of sulla. Results pointed out that rhizobial inoculation is essential for the exploitation of sulla outside its traditional cropping area.

\section{Introduction}

Forage and pasture legumes represent basic components of production systems and should be fully exploited for their important functions and benefits, in order to meet the demand for sustainable cropping systems (Rochon et al., 2004; Frame, 2005; Sinclair and Vadez, 2012).

The short-lived perennial legume sulla [Sulla coronaria (L.) Medik] syn. Hedysarum coronarium L. (Choi and Ohashi, 2003) is native to the Mediterranean basin, where it is widely grown as a rainfed biennial forage crop in several countries. It is a nonbloating legume with remarkable adaptability to drought-prone and marginal environments and is used for hay, silage and as a pasture plant, because of its great forage value and versatility (Sulas et al., 1997; Borreani et al., 2003; Sulas, 2005). Peculiar characteristics of sulla forage deal with its high quality and beneficial concentrations of condensed tannins, which can contribute to improvement in animal health, thus limiting inputs of synthetic chemicals (Bonanno et al., 2011; Piluzza et al., 2013). New varieties of sulla have been released in Australia, Italy and Tunisia, and several papers also documented the significant genetic potential (Yates et al., 2006; Ruisi et al., 2011; Cordoba et al., 2013; Annicchiarico et al., 2014; Issolah et al., 2014). Sulla has a valuable capacity to improve soil fertility and to fix atmospheric nitrogen (N) (Sulas et al., 2009; Saia et al., 2016). Moreover, sulla has an important role in multifunctional agriculture (Sulas, 2005), whereas interesting features of its biomass that could support the production of biofuels are recently noticed (Amato et al., 2016).

The successful performance of a legume depends on the presence of specific $\mathrm{N}$-fixing root nodule bacteria (rhizobia) in the soil and a suitable matching of both plant and bacterial genotypes is required for the development of an effective $\mathrm{N}$-fixing symbiosis (Howieson, 1999).

Legumes inoculation and fertilisation practices may significantly affect systems sustainability (Cazzato et al., 2012). In fact, legume inoculation could be essential to assure adequate nodulation and $\mathrm{N}$-fixation when planting in areas where the crop have not been grown before and/or to optimise legume yields by the selection of superior N-fixing strains capable of more effective symbioses (Amarger, 2001; Herridge et al., 2002).

Sulla is involved in a host-specific nitrogen-fixing symbiotic 
interaction with Rhizobium sullae (Vendramin et al., 2002). It was reported that sulla cultivation away from its natural habitat requires inoculation to ensure adequate nodulation, because of the absence of compatible natural populations of rhizobia (Casella et al., 1984; Thami-Alami and El Mzouri, 2000; de Koning et al., 2010; Fitouri et al., 2012). The strain WSM1592 of $R$. sullae, isolated from nodules recovered from $S$. coronaria in Sardinia, is highly effective at fixing $\mathrm{N}$, and it is the commercial sulla inoculant strain produced in Australia (Yates et al., 2015). It is a peatbased inoculant and just imported and available in Europe, representing a novel and valuable opportunity for farmers aimed at extending the cultivation area of the sulla crop. On the contrary, the ancient method for its inoculation (called assullamento in Italy and performed by mixing seeds with soil samples, containing root nodule bacteria, from fields where sulla was already present) and the only sporadic availability of liquid inoculants proved to be unable methods for supporting the extension on large scale of sulla cropping in new environments and countries. In fact, the transportation of soil particles from existing sulla crops was limited to adjacent or very close fields, whereas the main disadvantage of a liquid inoculant deals with the impossibility of its storing, due to the fast dissecation and subsequent high mortality of bacteria.

Regarding legume $\mathrm{N}$ fertilisation, it is still a controversial issue. Several Authors referred on the use of starter N coupled with legume inoculation at sowing. However, Namvar et al. (2012) concluded that $\mathrm{N}$ fertilisation as a starter can be beneficial to improve growth, development, physiological traits and total yield of inoculated chikpea (Cicer arietinum L.). On the contrary, Di Paolo et al. (2015) stated that $\mathrm{N}$ fertilisation was not a determining factor for faba bean (Vicia faba L.) performances. Chemining'wa et al. (2007) also concluded that it was not necessary to apply starter $\mathrm{N}$ for several inoculated grain and forage legumes. Voisin et al. (2002) pointed out that nitrate availability in the soil ploughed layer was shown to inhibit both initiation and activity of symbiotic $\mathrm{N}$-fixation in pea (Pisum sativum L.). On the other hand, a farm survey, for estimating the $\mathrm{N}$ surplus (using the method proposed by Simon and Le Corre, 1992) in Sardinian dairy sheep farms, evidenced improper but substantial $\mathrm{N}$ fertilisation applications on perennial forage legumes that were based on farmer empirical observations (Caredda et al., 1997). Therefore, it is important to investigate the effect of nitrate exposure not only on the productive performances of sulla crop but also on its N-fixation ability. Knowledge on recorded performances and peculiar agronomic traits of sulla specifically in the Mediterranean context is required to assess the feasibility of the sulla crop extension to new areas of cultivation. This enables informed decisions on agricultural landscape management with the aim of exploiting productive and environmental benefits from this legume and increasing the sustainability of Mediterranean cropping and farming systems.

The main objective of this research was to assess the effects of inoculation and inorganic $\mathrm{N}$ fertilisation on growth, productive performances, and $\mathrm{N}$-fixation ability of sulla crop when introduced in a new area of cultivation outside its traditional cropping environment.

\section{Materials and methods}

\section{Locations, experimental design and crop management}

The research was carried out during 2013-14 in a private agropastoral farm (Villanova Monteleone municipality, $40^{\circ} 49^{\prime} 74^{\prime \prime} \mathrm{N}$, $8^{\circ} 28^{\prime} 14^{\prime \prime}$ E, elevation $357 \mathrm{~m}$ a.s.1.) located in North Sardinia (Italy). The area is characterised by extensive agro-pastoral systems, typical of North Sardinia and similar semi-arid areas of the Mediterranean basin. Main land use is represented by the traditional Sarda dairy ewe farming with pasture as primary feeding source. Natural pastures could be occasionally fertilised, and/or ploughed for the establishment of annual forage crops.

The soil, classified as Lithic Xerorthents (Soil Survey Staff, 1999), has neutral $\mathrm{pH}$ (7.2) and loamy texture with adequate contents of nitrogen (2\%o), phosphorous (29 ppm), organic matter $(3.9 \%)$, and organic carbon $(2.2 \%)$. Moreover, the soil has been left uncultivated for the last 40 years, and sulla crop was never sown either in the farm either in the surrounding area or was present as spontaneous plant. The sulla crop was established in September 2013, after soil ploughing and seedbed preparation at a sowing density of 300 seeds $\mathrm{m}^{-2}$. Before sowing, soils was fertilised with $100 \mathrm{~kg} \mathrm{ha}^{-1}$ of $\mathrm{P}_{2} \mathrm{O}_{5}$ and sulla seeds were surface sterilised by immersion in ethanol $90 \%$, rinsed in sterile distilled water and allowed to dry. Considering the aim of the experiment and to avoid contamination risk among inoculation treatments, sulla Sardinian ecotype was manually sowed in $15 \mathrm{~m}$ length spaced rows (1.0 m apart). Each plot consisted of three sulla rows.

The following inoculation techniques plus an un-inoculated control were compared:

i) PE1, inoculation with the current Australian commercial inoculant strain for sulla (Rhizobium sullae, group C, strain WSM 1592), which was kindly provided by the Department of Agriculture and Food of Western Australia at the recommended rate; inoculation was performed using a peat-slurry inoculant as described by Yates et al. (2010);

ii) PE2, as PE1, but applied at a double rate;

iii) LIQ, using a liquid inoculant for sulla applied to sulla before sowing, kindly supplied by University of Sassari, Department of Agricultural Sciences, Microbiology Section, who also isolated the strain;

iv) SOI, the ancient inoculation method for sulla (assullamento) by mixing seed with soil from a field where sulla is usually grown and/or native;

v) CON, un-inoculated control, i.e., sulla seed kept un-inoculated and sowed before other treatments to avoid contaminations.

Additional rows were also sowed with Avena sativa L. (oats) at a rate of $180 \mathrm{~kg} \mathrm{ha}^{-1}$.

The above mentioned inoculation treatments exactly correspond to the inoculation techniques that are actually available from farmers. Moreover, each plot was split into two subplots: a subplot was fertilised in November, to minimise the risk of $\mathrm{N}$ leaching, with ammonium nitrate fertiliser at a rate of $100 \mathrm{~kg} \mathrm{ha}^{-1}$ of $\mathrm{N}(\mathrm{N} 100)$, and a subplot was left unfertilised (N0). The experimental design consisted of a split-plot with inoculation factor in main plot and $\mathrm{N}$ fertilisation in subplot and three replications.

In the same experiment, the $\mathrm{N}$-fixation ability of sulla crop was estimated by the ${ }^{15} \mathrm{~N}$ isotopic dilution method (Unkovich et al., 2008), using oats as non-fixing reference species (NFS). For sulla and oats, enriched ${ }^{15} \mathrm{~N}$ fertiliser (10 atom $\%{ }^{15} \mathrm{~N}$ enriched ammonium sulphate) was applied to a $3 \mathrm{~m}^{2}(1 \mathrm{~m} \times 3.0 \mathrm{~m})$ area at a rate of $4 \mathrm{~kg} \mathrm{~N} \mathrm{ha}^{-1}$ at seedling emergence. The ${ }^{15} \mathrm{~N}$-enriched fertiliser was diluted in water and uniformly hand-sprayed at a rate of $1 \mathrm{~L} \mathrm{~m}^{-2}$ to allow a uniform distribution in the soil profile. Plant emergence was recorded one week after sowing and it was regular. Across the subsequent season, representative shoot samples (30 cm length) within the $3 \mathrm{~m}^{2}{ }^{15} \mathrm{~N}$ labelled area along the row containing plants were cut in late winter, early, mid and late spring, respectively, at 140, 170, 200 and 240 days after sowing. The four sampling dates 
corresponded to the following morphological stages of development for individual sulla stems: 1 (mid vegetative), 2 (late vegetative), 3 (flowering), and 8 (seed set), as codified by Borreani et al. (2003)

Fresh shoots were weighted and then oven-dried at $60^{\circ} \mathrm{C}$ until constant weight and dry matter (DM) content was calculated. Dry sub-samples of shoots were ground finely enough to pass through a $1 \mathrm{~mm}$ mesh and submitted by dry combustion to elemental analyser isotope ratio mass spectrometry at the laboratory IsoAnalytical Limited (Cheshire, United Kingdom) to determine both $\mathrm{N}$ content $(\% \mathrm{~N})$ and the atom $\%{ }^{15} \mathrm{~N}$.

\section{Calculations}

Nitrogen yield $\left(\mathrm{kg} \mathrm{N} \mathrm{ha}^{-1}\right)$ was calculated by multiplying DM yield $\left(\mathrm{kg} \mathrm{ha}^{-1}\right)$ per its $\mathrm{N}$ content $(\%)$. The proportion of $\mathrm{N}$ derived from the atmosphere $(\% \mathrm{Ndfa})$ in sulla shoots was calculated according to the ${ }^{15} \mathrm{~N}$ isotopic dilution method (Warembourg, 1993) using the following equation:

$\% \mathrm{Ndfa}=\left(1-\frac{\text { atom } \%{ }^{15} \text { Nexcess }_{\text {sula }}}{\text { atom } \%^{15} \text { Nexcess }_{\text {oats }}}\right) \times 100$

where atom $\%{ }^{15} \mathrm{~N}$ excess $=\left(\right.$ atom $\%{ }^{15} \mathrm{~N}$ sample-atom $\%{ }^{15} \mathrm{~N} \mathrm{~N}_{2}$ air) and atom $\%{ }^{15} \mathrm{~N}$ of air $\mathrm{N}_{2}=0.3663$.

The amount of $\mathrm{N}$ fixed (Nfix) by sulla was than computed:

Nfix $\left(\mathrm{kg} \mathrm{ha}^{-1}\right)=$ sulla $\mathrm{N}\left(\mathrm{kg} \mathrm{ha}^{-1}\right) \times \frac{\% N d f a}{100}$

Eq. 2

\section{Statistical analysis}

The effect of inoculation techniques (inoculation), $\mathrm{N}$ fertilisation rates (fertilisation), and the interaction inoculation $\mathrm{x}$ fertilisation on plant height, DM yield, $\% \mathrm{~N}$, total $\mathrm{N}$, atom $\%{ }^{15} \mathrm{~N}$ excess in the aerial DM, \%Ndfa, fixed $\mathrm{N}$, were tested using PROC MIXED in SAS (version 9.02 SAS Institute, Cary, NC, USA). The analysis of variance was conducted separately within date of sampling, considering inoculation and fertilisation as fixed factors. Block and interactions with blocks were treated as random factors. The degrees of freedom were determined based on the Kenward-Roger method. Least squares means for inoculation, fertilisation, and interactions were separated by the SAS PDIFF option. All differences were considered significant at the 0.05 probability level.

\section{Results}

During the year 2013-14, annual rainfall exceeded $600 \mathrm{~mm}$ and was about $10 \%$ higher compared to the climatic mean; temperatures slightly differed from the long-term values.

Across the different sampling dates, the statistical analysis showed significant differences caused by inoculation and fertilisation on several examined parameters, as described thereafter.

\section{Plant height}

In the first sampling date, the average plant height was 34 and $42 \mathrm{~cm}$ for N0 and N100 plants, respectively, whereas it reached 123 and $130 \mathrm{~cm}$ at the last cut in late spring (Table 1). In the first sampling, there was a significant inoculation $\mathrm{x}$ fertilisation interaction for height (Table 1) and plants were significantly taller for N100 than for N0 on CON and LIQ.

Plant height significantly differed between N0 and N100 for LIQ and $\mathrm{CON}$ in the second sampling and for CON only in the third sampling. Moreover, plant height of CON and LIQ in N0 was significantly lower than the remaining treatments. In the third sampling, plant height of SOI and PE2 in N100 was significantly higher than the remaining treatments and, again, plants were significantly taller for N100 than for N0 on CON. The statistical analysis did not show significant differences at the fourth sampling.

\section{Shoot dry matter}

Across all samplings, DM yield was significantly affected by inoculation and fertilisation and, at the third sampling, the interaction of the inoculation $\times$ fertilisation was also significant (Table 2). In the first sampling, SOI and PE2 yielded 2.3 and $1.7 \mathrm{t} \mathrm{ha}^{-1}$, significantly higher than remaining treatments; DM significantly differed between N0 and N100 for LIQ and CON and for CON in the first and second sampling, respectively. In the third and fourth sampling, DM significantly differed between N0 and N100 for SOI

Table 1. Average ( \pm standard error) sulla plant height $(\mathrm{cm})$ as affected by inoculation and fertiliser nitrogen at the four samplings.

\begin{tabular}{|c|c|c|c|c|c|c|c|c|c|c|c|}
\hline \multirow[t]{2}{*}{ Sampling } & \multicolumn{3}{|c|}{1} & \multicolumn{3}{|c|}{2} & \multicolumn{3}{|c|}{3} & \multicolumn{2}{|l|}{4} \\
\hline & NO & N100 & $\mathbf{P}$ & NO & N100 & $\mathbf{P}$ & NO & N100 & $\mathbf{P}$ & NO & N100 \\
\hline SOI & $42.1( \pm 6.3)$ & $47.6( \pm 5.5)$ & ns & $61.0( \pm 9.2)^{\mathrm{a}}$ & $60.2( \pm 11.4)$ & ns & $116.7( \pm 7.9)^{\mathrm{a}}$ & $123.0( \pm 8.3)^{\mathrm{a}}$ & ns & $131.3( \pm 9.8)$ & $140.6( \pm 11.2)$ \\
\hline PE1 & $37.1( \pm 6.9)$ & $41.3( \pm 6.8)$ & ns & $55.3( \pm 10.2)^{\mathrm{a}}$ & $63.7( \pm 9.3)$ & ns & $111.7( \pm 7.7)^{\mathrm{a}}$ & $103.7( \pm 6.2)^{b}$ & ns & $122.5( \pm 8.4)$ & $134.2( \pm 10.3)$ \\
\hline PE2 & $43.2( \pm 5.8)$ & $44.5( \pm 5.3)$ & ns & $69.4( \pm 10.3)^{\mathrm{a}}$ & $61.2( \pm 9.3)$ & ns & $108.0( \pm 6.9)^{\mathrm{a}}$ & $120.0( \pm 8.1)^{\mathrm{a}}$ & ns & $130.4( \pm 11.1)$ & $124.6( \pm 9.4)$ \\
\hline LIQ & $22.7( \pm 6.2)$ & $34.2( \pm 6.9)$ & $*$ & $35.4( \pm 7.2)^{b}$ & $49.1( \pm 6.0)$ & $*$ & $90.3( \pm 5.1)^{b}$ & $97.3( \pm 5.3)^{\mathrm{c}}$ & ns & $116.6( \pm 7.1)$ & $131.2( \pm 9.8)$ \\
\hline CON & $21.2( \pm 6.9)$ & $44.3( \pm 6.4)$ & $* * *$ & $25.5( \pm 4.1)^{\mathrm{c}}$ & $57.8( \pm 6.3)$ & $*$ & $61.0( \pm 5.0)^{\mathrm{c}}$ & $103.3( \pm 6.8)^{b}$ & $* * *$ & $114.4( \pm 7.2)$ & $116.8( \pm 7.5)$ \\
\hline Average & 33.5 & 42.4 & & 49.3 & 58.4 & & 97.5 & 109.5 & & 123.0 & 129.5 \\
\hline & $P$ & & & $P$ & & & $P$ & & & $P$ & \\
\hline Inoculation (I & ns & & & $*$ & & & $* *$ & & & ns & \\
\hline $\mathrm{N}$ rates $(\mathrm{N})$ & $* * *$ & & & $*$ & & & $*$ & & & ns & \\
\hline $\mathrm{I} \times \mathrm{N}$ & $*$ & & & ns & & & ns & & & ns & \\
\hline
\end{tabular}


and PE1 and for SOI, respectively; however, DM from CON and LIQ in N100 was significantly lower than the remaining treatments. It is worth noting that, within N0, DM of CON only represented about $21,22,10$ and $11 \%$ of the best inoculated treatment in the first, second, third and fourth sampling, respectively.

Fertilisation produced considerable gains in DM yield of CON that was three-fold as high in N100 as in N0 in the first and second sampling, respectively. SOI and PE1 (third sampling date) and SOI (fourth sampling date) were positively affected by N100 fertilisation (Table 2).

\section{Shoot nitrogen content (\%)}

At the first sampling, $\% \mathrm{~N}$ was significantly affected by both inoculation and fertilisation (Table 3). Under both N0 and N100, the N content of SOI, PE1 and PE2 was significantly higher than LIQ and CON. Within N0, N content of SOI was twice as high as the value of CON. Compared to N0, N100 treatment significantly increased N content of LIQ and CON by 40 and $67 \%$, respectively.

In the second sampling, $\mathrm{N}$ content was significantly affected by inoculation and showed the greatest value for PE2, SOI and LIQ treatments, and the lowest for $\mathrm{CON}$. On average, the $\mathrm{N}$ content reached 2.5 and $2.3 \%$ in $\mathrm{N} 0$ and N100, respectively, at the third sampling date, than, in the last sampling, decreased to about $1.8 \%$, as average of both $\mathrm{N} 0$ and N100, evidencing no effects from the studied factors compared to earlier stages.

\section{Nitrogen yield}

Nitrogen yield was significantly affected by inoculation for all the considered dates of sampling. The treatment CON was always the lowest, except for the second sampling date within N100 (Table 4). In the first sampling, N100 significantly increased N yield of LIQ and CON. It worth noting that, within N0, N yield of CON represented only $10,18,12$ and $10 \%$ of the best inoculated treatment in the first, second, third and fourth sampling, respectively, indicating that $\mathrm{N}$ yield markedly decreased without inoculation. However, $\mathrm{N}$ yield of the CON within N100, represented in the same order $60,73,38$, and $32 \%$ of the best inoculated treatment, showing that, at the first and second sampling date, fertilisation was more efficient in increasing $\mathrm{N}$ yield by partially substituting for the atmospheric $\mathrm{N}$.

Table 2. Average ( \pm standard error) dry matter yield $\left(\mathrm{kg} \mathrm{ha}^{-1}\right)$ of sulla shoots as affected by inoculation and fertiliser nitrogen at the four samplings.

\begin{tabular}{|c|c|c|c|c|c|c|c|c|c|c|c|c|}
\hline \multirow{2}{*}{ Sampling } & \multicolumn{3}{|c|}{1} & \multicolumn{3}{|c|}{2} & \multicolumn{3}{|c|}{3} & \multicolumn{3}{|c|}{4} \\
\hline & NO & N100 & $\mathbf{P}$ & NO & N100 & $\mathbf{P}$ & NO & N100 & P & NO & N100 & $\mathbf{P}$ \\
\hline SOI & $2290( \pm 329)^{\mathrm{a}}$ & $1956( \pm 332)$ & ns & $4253( \pm 1256)^{\mathrm{a}}$ & $2940( \pm 814)$ & ns & $4059( \pm 845)^{\mathrm{a}}$ & $8423( \pm 967)^{\mathrm{a}}$ & $* *$ & $11755( \pm 1316)^{\mathrm{a}}$ & $15417( \pm 1718)^{a}$ & $*$ \\
\hline PEl & $1275( \pm 255)^{b}$ & $1292( \pm 169)$ & ns & $5034( \pm 1053)^{\mathrm{a}}$ & $3181( \pm 1125)$ & ns & $4215( \pm 743)^{\mathrm{a}}$ & $9443( \pm 1205)^{\mathrm{a}}$ & $* * *$ & $12660( \pm 1504)^{\mathrm{a}}$ & $9104( \pm 1205)^{\mathrm{c}}$ & ns \\
\hline PE2 & $1733( \pm 177)^{\mathrm{a}}$ & $1907( \pm 196)$ & ns & $4267( \pm 1400)^{\mathrm{a}}$ & $2864( \pm 722)$ & ns & $5504( \pm 531)^{\mathrm{a}}$ & $6131( \pm 1041)^{b}$ & ns & $14907( \pm 1780)^{\mathrm{a}}$ & $11315( \pm 1416)^{b}$ & ns \\
\hline LIQ & $480( \pm 336)^{c}$ & $1683( \pm 223)$ & $*$ & $1881( \pm 503)^{b}$ & $1500( \pm 432)$ & ns & $1874( \pm 409)^{b}$ & $2495( \pm 669)^{c}$ & ns & $5922( \pm 716)^{b}$ & $10421( \pm 1312)^{c}$ & ns \\
\hline $\mathrm{CON}$ & $472( \pm 369)^{\mathrm{c}}$ & $1581( \pm 276)$ & * & $1131( \pm 411)^{b}$ & $3679( \pm 1114)$ & $*$ & $530( \pm 223)^{c}$ & $2614( \pm 820)^{c}$ & ns & $1616( \pm 1007)^{c}$ & $5237( \pm 805)^{\mathrm{d}}$ & ns \\
\hline Average & 1250 & 1683.8 & & 3313 & 2832 & & 3236 & 5821 & & 9372 & 10298 & \\
\hline & $\mathrm{P}$ & & & $\mathrm{P}$ & & & $P$ & & & $\mathrm{P}$ & & \\
\hline Inoculation (I) & $*$ & & & * & & & $* *$ & & & $* *$ & & \\
\hline $\mathrm{N}$ rates $(\mathrm{N})$ & $*$ & & & $*$ & & & $* * *$ & & & $*$ & & \\
\hline $\mathrm{I} \times \mathrm{N}$ & ns & & & ns & & & $*$ & & & ns & & \\
\hline
\end{tabular}

N0, unfertilised treatment; N100, $100 \mathrm{~kg} \mathrm{ha}^{-1}$ of nitrogen; SOI, ancient inoculation method; PE1, peat inoculation; PE2, as PE1 but at a double rate; LIQ, liquid inoculant; CON; un-inoculated control. a-dIn the columns of $\mathrm{N}$ fertiliser applications within sampling date, means followed by the same letters are not significantly different at $\mathrm{P}<0.05$ level. In the rows, LSMEANS test for $\mathrm{N}$ fertiliser effect on each type of inoculation. ${ }^{*} \mathrm{P} \leq 0.05$; **P $\leq 0.01 ; * * \mathrm{P} \leq 0.001 ;$ ns, not significant.

Table 3. Average ( \pm standard error) nitrogen content of sulla shoots ( $\%$ dry matter) as affected by inoculation and fertiliser nitrogen at the four samplings.

\begin{tabular}{|c|c|c|c|c|c|c|c|c|c|}
\hline \multirow[t]{2}{*}{ Sampling } & \multicolumn{3}{|c|}{1} & \multicolumn{2}{|c|}{2} & \multicolumn{2}{|c|}{3} & \multicolumn{2}{|c|}{4} \\
\hline & NO & N100 & $\mathbf{P}$ & NO & N100 & NO & N100 & NO & N100 \\
\hline SOI & $2.000( \pm 0.1)^{\mathrm{a}}$ & $2.267( \pm 0.1)^{\mathrm{a}}$ & ns & $1.843( \pm 0.2)^{\mathrm{a}}$ & $1.917( \pm 0.2)^{\mathrm{a}}$ & $2.474( \pm 0.2)$ & $2.239( \pm 0.2)$ & $1.692( \pm 0.1)$ & $1.682( \pm 0.1)$ \\
\hline PE1 & $1.933( \pm 0.1)^{\mathrm{a}}$ & $2.233( \pm 0.1)^{\mathrm{a}}$ & ns & $1.387( \pm 0.1)^{b}$ & $1.623( \pm 0.1)^{b}$ & $2.774( \pm 0.2)$ & $1.872( \pm 0.3)$ & $1.799( \pm 0.1)$ & $1.850( \pm 0.1)$ \\
\hline PE2 & $1.733( \pm 0.3)^{\mathrm{a}}$ & $2.033( \pm 0.2)^{\mathrm{a}}$ & ns & $1.887( \pm 0.1)^{\mathrm{a}}$ & $2.140( \pm 0.2)^{\mathrm{a}}$ & $2.119( \pm 0.2)$ & $2.561( \pm 0.2)$ & $1.797( \pm 0.1)$ & $1.847( \pm 0.1)$ \\
\hline LIQ & $1.267( \pm 0.1)^{\mathrm{b}}$ & $1.767( \pm 0.2)^{b}$ & $*$ & $1.820( \pm 0.1)^{\mathrm{a}}$ & $1.750( \pm 0.1)^{\mathrm{a}}$ & $2.273( \pm 0.2)$ & $2.797( \pm 0.3)$ & $1.917( \pm 0.1)$ & $2.000( \pm 0.1)$ \\
\hline CON & $1.033( \pm 0.2)^{\mathrm{c}}$ & $1.733( \pm 0.3)^{b}$ & $* *$ & $1.230( \pm 0.1)^{\mathrm{c}}$ & $1.207( \pm 0.1)^{\mathrm{c}}$ & $3.010( \pm 0.3)$ & $2.138( \pm 0.3)$ & $1.636( \pm 0.1)$ & $1.909( \pm 0.1)$ \\
\hline Average & 1.593 & 2.007 & & 1.633 & 1.727 & 2.530 & 2.321 & 1.768 & 1.858 \\
\hline & $\mathrm{P}$ & & & $\mathrm{P}$ & & $\mathrm{P}$ & & $P$ & \\
\hline Inoculation (I) & $* * *$ & & & $* * *$ & & ns & & ns & \\
\hline $\mathrm{N}$ rates $(\mathrm{N})$ & $* * *$ & & & ns & & ns & & ns & \\
\hline $\mathrm{I} \times \mathrm{N}$ & ns & & & ns & & ns & & ns & \\
\hline
\end{tabular}

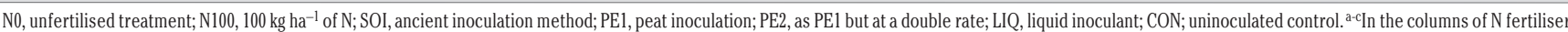
applications within sampling date, means followed by the same letters are not significantly different at $\mathrm{P}<0.05$ level. In the rows, LSMEANS test for $\mathrm{N}$ fertiliser effect on each type of inoculation. ${ }^{*} \mathrm{P} \leq 0.05$; ${ }^{* *} \mathrm{P} \leq 0.01$; ***P $\leq 0.001$; ns, not significant. 


\section{Atom $\%{ }^{15} \mathrm{~N}$ excess}

At the first sampling, atom $\%{ }^{15} \mathrm{~N}$ excess ranged from 0.0143 to 0.1350 in SOI (N0) and LIQ (N100), and there was a significant interaction between inoculation and fertilisation (Table 5). Atom $\%$ ${ }^{15} \mathrm{~N}$ excess did not significantly differ between N0 and N100 for PE1 and PE2. However, for SOI, LIQ, and CON, atom $\%{ }^{15} \mathrm{~N}$ excess was significantly higher for N100. Under both N0 and $\mathrm{N} 100$, the atom $\%{ }^{15} \mathrm{~N}$ excess of SOI, PE1 and PE2 were significantly lower than LIQ and CON.

At the second sampling, atom $\%{ }^{15} \mathrm{~N}$ excess was significantly affected by both inoculation and fertilisation. On PE1, N100 treatment was significantly higher than N0. Under N0, the atom $\%{ }^{15} \mathrm{~N}$ excess of $\mathrm{CON}$ was the highest.

During the last two samplings, atom $\%{ }^{15} \mathrm{~N}$ excess was significantly affected by fertilisation only, with significant but slight increases for PE1. On average, atom $\%{ }^{15} \mathrm{~N}$ excess for $\mathrm{N} 0$ ranged from 0.023 to 0.012 , and 0.008 to 0.004 , in the third and fourth sampling, respectively, indicating a progressive reduction across the season. At each sampling date, the atom $\%{ }^{15} \mathrm{~N}$ excess values in oats used as NFS (data not reported) were always higher than in sulla.

\section{Nitrogen derived from the atmosphere (\%)}

The \%Ndfa was significantly affected by inoculation and fertilisation during the first two sampling dates (Table 6). In the first sampling, N100 significantly reduced \%Ndfa of SOI, PE2 and LIQ (Table 6) and, within both N0 and N100, the Ndfa value of SOI, PE1 and PE2 were significantly higher than LIQ and CON. In the second sampling, N100 significantly reduced \%Ndfa of PE1 and, again, $\mathrm{CON}$ showed the lowest value. In the third sampling, no significant differences were found and a substantially increase in the $\%$ Ndfa was noticed for SOI. During the fourth sampling, \%Ndfa was significantly affected by fertilisation and N100 significantly reduced $\%$ Ndfa of PE1.

\section{Fixed nitrogen}

Fixed $\mathrm{N}$ was significantly affected by inoculation across all samplings and was always higher for SOI, PE1 and PE2 treatments than for LIQ, and CON, except for LIQ (second sampling) and PE1

Table 4. Average ( \pm standard error) sulla nitrogen yield $\left(\mathrm{kg} \mathrm{ha}^{-1}\right)$ as affected by inoculation and fertiliser nitrogen at the four samplings.

\begin{tabular}{|c|c|c|c|c|c|c|c|c|c|}
\hline \multirow[t]{2}{*}{ Sampling } & \multicolumn{3}{|c|}{1} & \multicolumn{2}{|c|}{2} & \multicolumn{2}{|c|}{3} & \multicolumn{2}{|c|}{4} \\
\hline & NO & N100 & $P$ & NO & N100 & NO & N100 & NO & N100 \\
\hline SOI & $45.2( \pm 5.9)^{\mathrm{a}}$ & $44.7( \pm 5.1)^{\mathrm{a}}$ & ns & $78.5( \pm 22.1)^{\mathrm{a}}$ & $56.1( \pm 15.1)$ & $100.3( \pm 25.1)^{\mathrm{a}}$ & $185.6( \pm 29.2)^{\mathrm{a}}$ & $201.7( \pm 29.2)^{\mathrm{a}}$ & $259.3( \pm 33.1)^{\mathrm{a}}$ \\
\hline PEl & $24.2( \pm 6.8)^{\mathrm{b}}$ & $28.9( \pm 4.9)^{\mathrm{b}}$ & ns & $64.8( \pm 19.1)^{\mathrm{a}}$ & $56.9( \pm 15.0)$ & $127.4( \pm 15.0)^{\mathrm{a}}$ & $168.8( \pm 18.1)^{\mathrm{a}}$ & $226.6( \pm 19.1)^{\mathrm{a}}$ & $168.5( \pm 21.0)^{b}$ \\
\hline PE2 & $30.3( \pm 6.9)^{\mathrm{a}}$ & $38.5( \pm 5.8)^{\mathrm{a}}$ & ns & $80.3( \pm 25.3)^{\mathrm{a}}$ & $62.0( \pm 20.2)$ & $123.0( \pm 16.3)^{\mathrm{a}}$ & $159.2( \pm 17.4)^{\mathrm{a}}$ & $267.2( \pm 17.0)^{\mathrm{a}}$ & $209.0( \pm 29.3)^{\mathrm{a}}$ \\
\hline LIQ & $6.0( \pm 6.1)^{\mathrm{c}}$ & $29.3( \pm 5.4)^{\mathrm{a}}$ & $*$ & $32.4( \pm 7.6)^{b}$ & $26.3( \pm 5.7)$ & $44.0( \pm 5.5)^{\mathrm{a}}$ & $70.0( \pm 4.0)^{b}$ & $112.8( \pm 18.0)^{b}$ & $206.3( \pm 19.5)^{\mathrm{a}}$ \\
\hline $\mathrm{CON}$ & $4.8( \pm 6.0)^{\mathrm{c}}$ & $27.6( \pm 5.9)^{b}$ & $*$ & $14.6( \pm 5.0)^{\mathrm{c}}$ & $41.3( \pm 13.7)$ & $15.5( \pm 2.3)^{b}$ & $56.0( \pm 10.4)^{\mathrm{c}}$ & $25.8( \pm 23.1)^{c}$ & $99.4( \pm 19.5)^{c}$ \\
\hline Average & 22.1 & 33.8 & & 54.1 & 43.0 & 82.0 & 127.9 & 166.8 & 198.5 \\
\hline & $P$ & & & $P$ & & $P$ & & $P$ & \\
\hline Inoculation (I) & $* *$ & & & $*$ & & $* *$ & & $* *$ & \\
\hline $\mathrm{N}$ rates $(\mathrm{N})$ & $* *$ & & & ns & & ns & & ns & \\
\hline $\mathrm{I} \times \mathrm{N}$ & ns & & & ns & & ns & & ns & \\
\hline
\end{tabular}

Table 5. Average ( \pm standard error) atom $\%{ }^{15} \mathrm{~N}$ excess of sulla shoots $\left(\%{ }^{15} \mathrm{~N}\right)$ as affected by inoculation and fertiliser nitrogen at the four samplings.

\begin{tabular}{|c|c|c|c|c|c|c|c|c|c|c|c|c|}
\hline Sampling & & 1 & & & 2 & & & 3 & & & 4 & \\
\hline & NO & N100 & P & NO & N100 & $\mathbf{P}$ & NO & N100 & $\mathbf{P}$ & NO & N100 & P \\
\hline SOI & $0.014( \pm 0.01)^{\mathrm{c}}$ & $0.081( \pm 0.01)^{b}$ & $* *$ & $0.016( \pm 0.01)^{\mathrm{c}}$ & $0.058( \pm 0.01)^{b}$ & ns & $0.013( \pm 0.01)$ & $0.013( \pm 0.01)$ & ns & $0.004( \pm 0.01)$ & $0.006( \pm 0.01)$ & ns \\
\hline PE1 & $0.026( \pm 0.01)^{c}$ & $0.048( \pm 0.01)^{\mathrm{c}}$ & ns & $0.036( \pm 0.01)^{b}$ & $0.102( \pm 0.01)^{a}$ & $*$ & $0.005( \pm 0.01)$ & $0.039( \pm 0.01)$ & $* *$ & $0.003( \pm 0.01)$ & $0.011( \pm 0.01)$ & $* * *$ \\
\hline PE2 & $0.017( \pm 0.01)^{\mathrm{c}}$ & $0.043( \pm 0.01)^{\mathrm{c}}$ & ns & $0.012( \pm 0.01)^{c}$ & $0.044( \pm 0.01)^{\mathrm{c}}$ & ns & $0.011( \pm 0.01)$ & $0.011( \pm 0.01)$ & ns & $0.005( \pm 0.01)$ & $0.006( \pm 0.01)$ & ns \\
\hline LIQ & $0.038( \pm 0.01)^{b}$ & $0.135( \pm 0.01)^{\mathrm{a}}$ & $* * *$ & $0.026( \pm 0.01)^{\mathrm{c}}$ & $0.068( \pm 0.01)^{b}$ & ns & $0.011( \pm 0.01)$ & $0.024( \pm 0.01)$ & ns & $0.002( \pm 0.01)$ & $0.006( \pm 0.01)$ & ns \\
\hline $\mathrm{CON}$ & $0.086( \pm 0.01)^{\mathrm{a}}$ & $0.123( \pm 0.01)^{\mathrm{a}}$ & $*$ & $0.115( \pm 0.01)^{\mathrm{a}}$ & $0.143( \pm 0.01)^{\mathrm{a}}$ & ns & $0.023( \pm 0.01)$ & $0.029( \pm 0.01)$ & ns & $0.007( \pm 0.01)$ & $0.011( \pm 0.01)$ & $\mathrm{ns}$ \\
\hline Average & 0.036 & 0.086 & & 0.041 & 0.083 & & 0.012 & 0.023 & & 0.004 & 0.008 & \\
\hline & $\mathrm{P}$ & & & $\mathrm{P}$ & & & $\mathrm{P}$ & & & $\mathrm{P}$ & & \\
\hline Inoculation ( & $* *$ & & & $* *$ & & & ns & & & ns & & \\
\hline $\mathrm{N}$ rates $(\mathrm{N})$ & $* * *$ & & & $*$ & & & $*$ & & & $* *$ & & \\
\hline $\mathrm{I} \times \mathrm{N}$ & $*$ & & & ns & & & ns & & & ns & & \\
\hline
\end{tabular}


(fourth sampling) within N100 (Table 7). In the first sampling, N100 significantly reduced fixed $\mathrm{N}$ of SOI and it reduced again fixed $\mathrm{N}$ of SOI and PE2 in the second sampling. Within N0, fixed $\mathrm{N}$ of CON only represented about $4,2,11$ and $10 \%$ of the best inoculated treatment in the first, second, third and fourth sampling, respectively.

\section{Discussion}

\section{Effects of inoculation and nitrogen fertilisation}

As rhizobia are widespread according to the natural presence or cultivation of legumes, it is essential to assure adequate crop nodulation and $\mathrm{N}$-fixation in new cultivation areas and/or where legumes have not been grown before, by the supplying of the bacterial microsymbionts to the legume (Amarger, 2001; Date, 2001; Deaker et al., 2004; Howieson et al., 2005). There is a general con- sensus on the mandatory inoculation for sulla grown outside the natural distribution area of its genus. However, few papers have reported findings from field experiments dealing with sulla inoculation in new areas of cultivation. Our research allowed for elucidating detailed effects caused by inoculation and $\mathrm{N}$ fertilisation on agronomic performances and $\mathrm{N}$-fixation ability of a sulla crop established in a new habitat. The more evident effects caused by inoculation and fertilisation deal with wide differences in plant height and DM yield found between inoculated treatments and control. Among inoculated treatments, overall LIQ showed reduced performances compared to SOI, PE1 and PE2. However, inoculated sulla produced from three to eight fold more shoot DM than it did the un-inoculated control, confirming that inoculation is essential for an effective symbiotic relationship in a new area of cultivation. Our findings are in agreement with previous results obtained in different countries. After the introduction of sulla in Israel, Gurfel et al. (1982) carried out field inoculation experiments with effective Rhizobium strains and reported seasonal

Table 6. Average ( \pm standard error) proportion of nitrogen derived from the atmosphere of sulla shoots as affected by inoculation and fertiliser nitrogen at the four samplings.

\begin{tabular}{|c|c|c|c|c|c|c|c|c|c|c|c|}
\hline Sampling & & 1 & & & 2 & & & & & 4 & \\
\hline & NO & N100 & $\mathbf{P}$ & No & N100 & P & NO & N100 & NO & N100 & $\mathbf{P}$ \\
\hline SOI & $89.8( \pm 7.9)^{\mathrm{a}}$ & $51.7( \pm 8.9)^{\mathrm{a}}$ & $* *$ & $85.5( \pm 7.2)^{\mathrm{a}}$ & $51.6( \pm 4.4)^{\mathrm{a}}$ & ns & $88.8( \pm 6.5)$ & $91.3( \pm 6.1)$ & $94.1( \pm 1.9)$ & $92.9( \pm 1.8)$ & ns \\
\hline PE1 & $77.0( \pm 6.4)^{\mathrm{a}}$ & $62.1( \pm 6.1)^{\mathrm{a}}$ & ns & $70.9( \pm 6.9)^{\mathrm{a}}$ & $28.7( \pm 3.9)^{b}$ & $*$ & $95.3( \pm 6.1)$ & $74.4( \pm 5.7)$ & $95.8( \pm 1.1)$ & $86.4( \pm 1.6)$ & $* * *$ \\
\hline PE2 & $87.3( \pm 7.7)^{\mathrm{a}}$ & $62.1( \pm 8.4)^{\mathrm{a}}$ & $*$ & $89.0( \pm 7.9)^{\mathrm{a}}$ & $63.3( \pm 7.2)^{\mathrm{a}}$ & ns & $90.7( \pm 6.8)$ & $92.8( \pm 7.3)$ & $93.5( \pm 1.7)$ & $92.8( \pm 1.6)$ & ns \\
\hline LIQ & $63.9( \pm 6.5)^{b}$ & $16.9( \pm 6.2)^{b}$ & $* * *$ & $77.1( \pm 7.9)^{\mathrm{a}}$ & $43.0( \pm 4.9)^{\mathrm{a}}$ & ns & $91.4( \pm 6.4)$ & $84.1( \pm 5.2)$ & $96.9( \pm 1.6)$ & $93.0( \pm 1.5)$ & ns \\
\hline CON & $32.9( \pm 5.3)^{\mathrm{c}}$ & $12.8( \pm 4.9)^{\mathrm{c}}$ & ns & $4.0( \pm 2.1)^{b}$ & $23.6( \pm 3.3)^{\mathrm{b}}$ & ns & $80.4( \pm 7.2)$ & $80.6( \pm 8.1)$ & $90.5( \pm 1.7)$ & $87.1( \pm 1.2)$ & ns \\
\hline Average & 70.2 & 41.1 & & 65.3 & 42.0 & & 89.3 & 84.6 & 94.2 & 90.4 & \\
\hline & $\mathrm{P}$ & & & $P$ & & & $\mathrm{P}$ & & $\mathrm{P}$ & & \\
\hline Inoculation (I) & $* *$ & & & $* * *$ & & & ns & & ns & & \\
\hline N rates $(\mathrm{N})$ & $* * *$ & & & $*$ & & & ns & & $* *$ & & \\
\hline $\mathrm{I} \times \mathrm{N}$ & ns & & & ns & & & ns & & ns & & \\
\hline
\end{tabular}

$\mathrm{N} 0$, unfertilised treatment; $\mathrm{N1} 100,100 \mathrm{~kg} \mathrm{ha}^{-1}$ of N; SOI, ancient inoculation method; PE1, peat inoculation; PE2, as PE1 but at a double rate; LIQ, liquid inoculant; CON; uninoculated control. ${ }^{\mathrm{a}-\mathrm{c}}$ In the columns of $\mathrm{N}$ fertiliser applications within sampling date, means followed by the same letters are not significantly different at $\mathrm{P}<0.05$ level. In the rows, LSMEANS test for $\mathrm{N}$ fertiliser effect on each type of inoculation.

${ }^{* P} \leq 0.05 ; * * \mathrm{P} \leq 0.01 ;{ }^{* *} \mathrm{P} \leq 0.001 ;$ ns, not significant.

Table 7. Average ( \pm standard error) fixed nitrogen in sulla shoots $\left(\mathrm{kg} \mathrm{ha}^{-1}\right)$ as affected by inoculation and fertiliser nitrogen at the four samplings.

\begin{tabular}{|c|c|c|c|c|c|c|c|c|c|c|}
\hline \multirow[t]{2}{*}{ Sampling } & \multicolumn{3}{|c|}{1} & \multicolumn{3}{|c|}{2} & \multicolumn{2}{|c|}{3} & \multicolumn{2}{|c|}{4} \\
\hline & NO & N100 & $\mathbf{P}$ & NO & N100 & $\mathbf{P}$ & NO & N100 & NO & N100 \\
\hline SOI & $40.7( \pm 3.9)^{\mathrm{a}}$ & $22.9( \pm 4.6)^{\mathrm{a}}$ & $* * *$ & $67.3( \pm 6.6)^{\mathrm{a}}$ & $28.9( \pm 4.5)^{\mathrm{a}}$ & $* *$ & $88.2( \pm 16.2)^{\mathrm{a}}$ & $169.9( \pm 26.7)^{\mathrm{a}}$ & $190.5( \pm 34.7)^{\mathrm{a}}$ & $240.8( \pm 29.1)^{\mathrm{a}}$ \\
\hline PE1 & $18.9( \pm 2.9)^{\mathrm{c}}$ & $18.4( \pm 3.6)^{\mathrm{a}}$ & ns & $45.5( \pm 5.1)^{\mathrm{a}}$ & $22.3( \pm 4.1)^{\mathrm{a}}$ & ns & $120.1( \pm 21.7)^{\mathrm{a}}$ & $125.7( \pm 18.1)^{\mathrm{a}}$ & $217.0( \pm 14.2)^{\mathrm{a}}$ & $146.1( \pm 13.6)^{\mathrm{c}}$ \\
\hline PE2 & $26.4( \pm 4.7)^{b}$ & $24.9( \pm 4.9)^{\mathrm{a}}$ & ns & $71.4( \pm 7.6)^{\mathrm{a}}$ & $38.2( \pm 3.3)^{\mathrm{a}}$ & $*$ & $109.2( \pm 22.1)^{\mathrm{a}}$ & $147.1( \pm 26.8)^{\mathrm{a}}$ & $250.1( \pm 16.3)^{\mathrm{a}}$ & $193.3( \pm 16.0)^{\mathrm{a}}$ \\
\hline LIQ & $4.0( \pm 0.9)^{\mathrm{d}}$ & $3.2( \pm 1.6)^{b}$ & ns & $24.4( \pm 1.1)^{b}$ & $11.3( \pm 0.6)^{\mathrm{a}}$ & ns & $40.5( \pm 5.6)^{b}$ & $59.0( \pm 4.5)^{\mathrm{b}}$ & $109.7( \pm 9.7)^{\mathrm{b}}$ & $191.8( \pm 11.7)^{\mathrm{b}}$ \\
\hline CON & $1.6( \pm 0.4)^{d}$ & $3.4( \pm 1.8)^{\mathrm{b}}$ & ns & $0.1( \pm 0.0)^{\mathrm{c}}$ & $4.1( \pm 0.0)^{\mathrm{b}}$ & ns & $12.2( \pm 1.0)^{\mathrm{c}}$ & $45.9( \pm 6.1)^{b}$ & $23.3( \pm 4.1)^{\mathrm{c}}$ & $114.5( \pm 3.7)^{\mathrm{c}}$ \\
\hline Average & 18.3 & 14.5 & & 41.7 & 20.9 & & 74.0 & 109.5 & 158.1 & 177.3 \\
\hline & $P$ & & & $P$ & & & $P$ & & $P$ & \\
\hline Inoculation (I) & $* *$ & & & $* *$ & & & $* *$ & & $* *$ & \\
\hline $\mathrm{N}$ rates $(\mathrm{N})$ & $*$ & & & $* *$ & & & ns & & ns & \\
\hline $\mathrm{I} \times \mathrm{N}$ & ns & & & ns & & & ns & & ns & \\
\hline
\end{tabular}

N0, unfertilised treatment; $\mathrm{N100}, 100 \mathrm{~kg} \mathrm{ha}^{-1}$ of N; SOI, ancient inoculation method; PE1, peat inoculation; PE2, as PE1 but at a double rate; LIQ, liquid inoculant; CON; uninoculated control. a-dIn the columns of N fertilise applications within sampling date, means followed by the same letters are not significantly different at $\mathrm{P}<0.05$ level. In the rows, LSMEANS test for $\mathrm{N}$ fertiliser effect on each type of inoculation. ${ }^{*} \mathrm{P} \leq 0.05 ;{ }^{* *} \mathrm{P} \leq 0.01$; ***P $\leq 0.001 ;$ ns, not significant. 
changes in plant DM accumulation caused by inoculation. In Spain, Rodriguez-Navarro et al. (1991), reported that sulla forage yields were significantly increased by rhizobial treatments above those of the un-inoculated control without combined N, except in the third harvest (16 months after sowing). Moreover, the un-inoculated $\mathrm{N}$ fertilised control did not significantly differ from rhizobial treatments. Previous results from Sardinia highlighted that different root-nodule bacteria strains affect the performances of sulla plants in both calcareous and acid soils, pointing out the importance of the choice of the most appropriate Rhizobium strain in relation to soil type (Sulas et al., 1998). In Western Australia, remarkable DM increases over the un-inoculated treatment were obtained when sulla was inoculated with rhizobial strains collected from Mediterranean basin (Yates et al., 1996; Ewing et al., 2001).

The $\mathrm{N}$ content of the inoculated and N fertilised-control (N100 $\mathrm{CON}$ ) was not significantly different from inoculated and N0 treatments, indicating that $\mathrm{N}$ fertilisation was not able to increase shoot $\mathrm{N}$ content, whereas it happened in the fertilised un-inoculated control only. Azcon-Aguilar et al. (1982) evidenced that rhizobia successfully established in the sulla rhizosphere stimulated DM yield and plants nutrient uptake beyond that achieved by adding a standard dose of a compound N-P-K fertiliser.

Even if $\mathrm{N}$-fixation is correlated with DM yield, inoculation and fertilisation clearly affected specific parameters such as atom $\%$ ${ }^{15} \mathrm{~N}$ excess and $\% \mathrm{Ndfa}$ that are independent from DM yield, according to the assumptions of isotopic dilution method. Atom $\%$ ${ }^{15} \mathrm{~N}$ excess of CON was highest in the first and second sampling date. Moreover, atom $\%{ }^{15} \mathrm{~N}$ excess values were sometimes increased by fertilisation. Both results are indicative of reduced dilution of atmospheric N, caused by the absence of inoculation and the $\mathrm{N}$ input from fertiliser. As a results of the above mentioned high values of atom $\%{ }^{15} \mathrm{~N}$ excess, $\% \mathrm{Ndfa}$ reached the lowest values in $\mathrm{CON}$ in the first and second sampling date, with a strong reduction of the proportion of $\mathrm{N}$ derived from fixation. However, this reduction was not maintained in the third and fourth sampling date when $\% \mathrm{Ndfa}$ of $\mathrm{CON}$ reached about 80 and $90 \%$, as average of N0 and N100, very close to the values observed in the inoculated treatments. The $\% \mathrm{Ndfa}$ increase in $\mathrm{CON}$ could be explained by a late contamination between $\mathrm{CON}$ and inoculated treatments determined by wild boar excavations on the plots that occurred at the end of winter. This has favoured a late $\mathrm{N}$-fixing activity in $\mathrm{CON}$, as also revealed by variation in atom $\%{ }^{15} \mathrm{~N}$ excess. Due to that contamination, and considering that in the adjacent large field un-inoculated sulla plants completely died just after the third sampling, the late performances for DM yield and fixed $\mathrm{N}$ recorded in unfertilised and un-inoculated control could be presumably overestimated.

Moreover, N100 fertilisation significantly decreased \%Ndfa due to increased level of mineral $\mathrm{N}$ in the soil at the time of first sampling. In fact, soil nitrate level may affect symbiotic $\mathrm{N}$-fixation due to inhibitory action on nodule initiation and delay of $\mathrm{N}$-fixation. A negative linear relationship between $\mathrm{N}$ rate and \% Ndfa has been reported for legumes species, such as white clover (Trifolium repens L.), pea (Pisum sativum L.) and Lotus japonicus, when plants received fertiliser $\mathrm{N}$ at sowing (Mac Duff et al., 1996; Waterer and Vessey, 1993; Voisin et al., 2002; Omrane and Chiurazzi, 2009). In addition, the use of starter doses of $\mathrm{N}$ fertiliser aimed at alleviating $\mathrm{N}$ deficiency symptoms during legume early growth is still a disputed issue, regarding the balance between actual benefits and possible nodulation reduction (Van Kessel and Hartley, 2000). Except for PE1, fertilisation did not affect $\% \mathrm{Ndfa}$ at the third and fourth sampling dates. This trend can be caused by the progressive reduction of soil nitrate availability at the end of the sulla growth cycle, as reported for pea (Voisin et al., 2002), and it is also in agreement with field experiment results indicating a short-term inhibition of pea $\mathrm{N}$-fixation after $\mathrm{N}$ application (Naudin et al., 2010). Finally, inoculation always affected fixed $\mathrm{N}$, whereas fertilisation in the first and second sampling only. As fixed $\mathrm{N}$ depend on $\mathrm{DM}, \% \mathrm{~N}$, atom $\%{ }^{15} \mathrm{~N}$ excess and $\% \mathrm{Ndfa}$, the low values recorded for $\mathrm{CON}$ at the third and fourth sampling, when $\% \mathrm{Ndfa}$ increased, were mainly determined by the lowest DM yields. In Israel, Gurfel et al. (1982) evidenced seasonal changes in $\mathrm{N}_{2}\left(\mathrm{C}_{2}-\right.$ $\mathrm{H}_{2}$ )-fixation activity under field conditions. Unfortunately, N-fixation results obtained with acetylene reduction assay by Gurfel et al. are not directly comparable with our results, based on the isotopic dilution method. Few papers have focussed on sulla N-fixation (Sulas et al., 2009; Saia et al., 2016) and, to the best of our knowledge, no other information is available regarding $\mathrm{N}$-fixation studies by isotopic method within field experiments dealing with the inoculation of the sulla crop with current commercial strains. Recent investigations rather deal with diversity of rhizobia nodulating sulla, selection of inoculant strains, molecular phylogenetic analysis, strain fingerprinting and species identification, extracellular polysaccharides produced by $R$. sullae strains (Muresu et al., 2005; Fitouri et al., 2012; Liu et al., 2012; Razika et al., 2012; Aliliche et al., 2016). However, these studies document increasing interest in the symbiotic interaction of sulla and great potential for the selection of high efficient Rhizobium strains for sulla inoculation in different environmental contests. Overall, our data indicate an effectiveness of the commercial inoculant in order to extend the cultivation of sulla crop in a new habitat, where plant growth is not allowed without a proper inoculation. Unfortunately, comparisons with other results from similar experiments are difficult due to the overall lack of information for southern European conditions. Even if the need of inoculation is a well-known issue in sulla crop, the large scale availability of a peat based commercial inoculant, specifically developed for sulla, is a very recent option and our research also documents its potential impact.

\section{Implications and potential benefits for the farming sys- tem and environment}

Sulla crop is commonly used to enhance productivity and sustainability of semi-arid farming systems and low-input agriculture by the enrichment of soil organic matter and N (Ruisi et al., 2011; Bouajila et al., 2014). Sulla features are coupled with its well known and appreciated agronomic role as pioner plant in poor and degraded soils, and as a key species for the control of soil water erosion risk, re-vegetation and conservation programmes. Soil organic carbon (SOC) positively affects several important soil properties and functions, varing among environments and management systems. C sequestration via agricultural soils is strongly correlated with the adopted cropping systems and has a potential to significantly contribute to climate change mitigation (Huber et al., 2001; Lazzerini et al., 2014). As regard Mediterranean conditions of North Sardinia, Seddaiu et al. (2013) evidenced that a light tillage (every 2-5 years as for sulla crop) did not strongly affect SOC accumulation in topsoil, and dejections from grazing sheep can limit the negative long term impact of tillage on SOC sequestration, due to organic matter inputs. Experimental observations on mixtures grassland species evidenced that the legume $\mathrm{N}$-fixation and the efficient use of $\mathrm{N}$ by companion grasses favour the development of the belowground biomass and, therefore, soil $\mathrm{C}$ and $\mathrm{N}$ inputs (Fornara and Tilman, 2008). Total soil $\mathrm{N}$ is associated with SOC and plays a key role in building soil fertility and enhancing soil productivity. Francaviglia et al. (2014) reported that SOC and 
total soil $\mathrm{N}$ levels were highly correlated and previous studies carried out in Sardinia highlighted the positive input of $\mathrm{N}$-fixation as soil N source (Sulas et al., 2013, 2016). Therefore, the amounts of fixed $\mathrm{N}$ estimated from this study are presumably able to positively affect total soil $\mathrm{N}$ and consequently SOC, taken into account the conservative contest associated with the sulla crop. Moreover, other inputs such as biomass residues, root turnover from both sulla crop and unsown non legumes species which benefit fixed $\mathrm{N}$ can, directly or indirectly, lead to positive effects on SOC (Francaviglia et al., 2014). Compared to previous estimates, the values of fixed $\mathrm{N}$ reported in this study are high (Sulas et al., 2009). Total absence of diseases on sulla plants, which has been observed in the new environment of cultivation, can contribute to partially explain the overall better performances. The sulla $\mathrm{N}$ balance may be affected by crop use, which could include several management and biomass removal options such as grazing, grazing plus hay cutting, green manuring, etc. However, our results confirm that sulla can be a relevant $\mathrm{N}$ source for rainfed Mediterranean cropping systems. Previous results also evidenced positive effects of grazing sulla forage on ewe milk production (Sulas et al., 1995; Di Grigioli et al., 2012) and the complementary grazing of sulla resulted useful for improving the nutrition and performance of sheep basically fed on grassland (Molle et al., 2008). Moreover, the milk of condensed tannin exposed ewes grazing sulla at flowering was high in beneficial $\omega 3$ fatty acids (Cabiddu et al., 2009) and other results confirm that sulla fresh forage exerts an antioxidant activity (Di Trana et al., 2015). The high nutritive value of sulla forage and its beneficial level of condensed tannins are reported to be associated to bloat save, faster growth rates in young sheep, increased protein use efficiency of rumen, and decreased gastrointestinal parasite infection, nitrogen restitution and methane production in ruminants (Woodward et al., 2002; Ramirez-Restrepo and Barry, 2005; Molle et al., 2009). Therefore, it is clear that important benefits for farming systems and environment can arise from the proper inoculation and successfully establishment of sulla and its inclusion into the existing forage system.

Finally, considering a novel land use option, specifically linked with bioenergy crops and bio-based products, which are nowadays very important in North Sardinia, where an important Southern Europe biorefinery is located (Centi and Perathoner, 2012), it is reasonable to state that the establishment of the sulla crop in an uncultivated pasture may lead to a more conservative land management compared with the establishment of conventional bioenergy crops. According to Amato et al. (2016), sulla crop should be also considered in meantime a promising bioenergy options at least for some specific energetic route and destination and/or a valuable crop option for increase the sustainability of bioenergy crops.

\section{Conclusions}

Research evidenced that inoculation is necessary in order to extend the cropping of sulla in a new habitat where it is absent as spontaneous or cultivated legume plant. Specific results demonstrated that inoculation and $\mathrm{N}$ fertilisation both affected growth, $\mathrm{DM}$ and $\mathrm{N}$ yields, and $\mathrm{N}$-fixation ability of the sulla crop. Minor differences were detected among the inoculation techniques actually available for farmers (i.e., peat-based and liquid inoculants, and soil). On the contrary, DM yield and fixed $N$ values of the uninoculated and unfertilised control only represented 10 to $22 \%$ and 2 to $11 \%$, respectively, of the best-inoculated treatment. Nitrogen fertilisation caused temporary decreases in the proportion of $\mathrm{N}$ derived from the atmosphere and fixed $\mathrm{N}$ of sulla, so reducing its $\mathrm{N}$ fixing ability.

Overall, results pointed out that inoculation of sulla with selected rhizobial strains represents a strategic tool for the full exploitation of this precious and multipurpose Mediterranean legume outside its traditional cropping area. Finally, the potential benefits for the sustainability of the farming system and for the environment, which are associated with the successfull inclusion of the sulla crop, should be carefully taken into account.

\section{References}

Aliliche K, Beghalem H, Landoulsi A, Chriki A, 2016. Molecular phylogenetic analysis of Rhizobium sullae isolated from Algerian Hedysarum flexuosum. A Van Leeuw. J. Microb. 109:897-906.

Amarger N, 2001. Rhizobia in the field. Adv. Agron. 73:109-68.

Amato G, Giambalvo D, Frenda AS, Mazza F, Ruisi P, Saia S, Di Miceli G, 2016. Sulla (Hedysarum coronarium L.) as potential feedstock for biofuel and protein. Bioenerg. Res. 9:711-9.

Annicchiarico P, Ruisi P, Di Miceli V, Pecetti L, 2014. Morphophysiological and adaptive variation of Italian germplasm of sulla (Hedysarum coronarium L.). Crop Pasture Sci. 65:206-13.

Azcon-Aguilar C, Barea JM, Azcon R, Olivares J, 1982. Effectiveness of Rhizobium and VA mycorrhiza in the introduction of Hedysarum coronarium in a new habitat. Agr. Environ. 7:199-206.

Bonanno A, Di Miceli G, Di Grigoli A, Frenda AS, Tornambè G, Giambalvo D, Amato G, 2011. Effects of feeding green forage of sulla (Hedysarum coronarium L.) on lamb growth and carcass and meat quality. Anim. 5:148-54.

Borreani G, Roggero PP, Sulas L, Valente ME, 2003. Quantifying morphological stage to predict the nutritive value in sulla (Hedysarum coronarium L.). Agron. J. 95:1608-17.

Bouajila K, Jeddi FB, Sanaa M, 2014. Effet de la décomposition des résidus de sulla (Hedysarum coronarium L.) sur l'évolution des caractéristiques chimiques de deux types de sol en climat aride Tunisien (In French with english abstract). J. Mater. Environ. Sci. 5:723-30.

Cabiddu A, Molle G, Decandia M, Spada S, Fiori M, Piredda G, Addis M, 2009. Responses to condensed tannins of flowering sulla (Hedysarum coronarium L.) grazed by dairy sheep: Part 2: Effects on milk fatty acid profile. Livest, Sci. 123:230-40.

Caredda S, Fara G, Re GA, Porqueddu C, Sulas L, 1997. Stima dei surplus di macronutrienti attraverso il metodo del bilancio apparente in sistemi foraggero-zootecnici ovini sardi. Riv. Agron. 31:505-11.

Casella S, Gault RR, Reynolds KC, Dyson JR, Brockwell J, 1984. Nodulation studies on legumes exotic to Australia: Hedysarum coronarium. Fems Microbiol. Lett. 22:37.45.

Cazzato E, Tufarelli V, Ceci E, Stellacci AM, Laudadio V, 2012. Quality, yield and nitrogen fixation of faba bean seeds as affected by sulphur fertilization. Acta Agri. Scand. Sect. B Soil Plant Sci. 62:732-8.

Centi G, Perathoner S, 2012. Is there a strategy for sustainable (green) chemistry in Italy? Chim. Ind. 10:86-90.

Chemining'wa GN, Muthomi JW, Theuri SWM, 2007. Effect of rhizobia inoculation and starter-N on nodulation, shoot biomass and yield of grain legumes. Asian J. Plant Sci. 6:1113-8.

Choi BH, Ohashi H, 2003. Generic criteria and infrageneric system 
for Hedysarum and related genera (PapilionoideaeLeguminosae). Taxonomy 52:567-76.

Córdoba EM, Nadal S, Román B, Gónzalez-Verdejo CI, 2013. Collection, characterization and evaluation of wild Hedysarum coronarium L. populations from Andalusia (southern Spain). Aust. J. Agr. Res. 7:165-72.

Date RA, 2001. Advances in inoculant technology: A brief review. Aust. J. Exp. Agr. 41:321-5.

de Koning C, Schutz P, Howie J, 2010. Sulla (Hedysarum coronarium) production sown with cover crops. In Proc. 15th Australian Agronomy Conference, Lincoln, New Zealand. Available from: http://www.regional.org.au/au/asa/2010/pastures-forage/dryland-perennials/6987_dekoningct.htm

Deaker R, Roughley R, Kennedy I, 2004. Legume seed inoculation technology - A review. Soil Biol. Biochem. 36:1275-88.

Di Grigoli A, Todaro M, Di Miceli G, Genna V, Tornambè G, Alicata ML, Bonanno A, 2012. Effects of continuous and rotational grazing of different forage species on ewe milk production. Small Rumin. Res. 106:29-36.

Di Paolo E, Garofalo P, Rinaldi M, 2015. Irrigation and nitrogen fertilization treatments on productive and qualitative traits of broad bean (Vicia faba var. minor L.) in a Mediterranean environment. Legume Res. 38:209-18.

Di Trana A, Bonanno A, Cecchini S, Giorgio D, Di Grigoli A, Claps S, 2015. Effects of Sulla forage (Sulla coronarium L.) on the oxidative status and milk polyphenol content in goats. J. Dairy Sci. 98:37-46.

Ewing M, Poole C, Skinner P, Bennett A, 2001. Sulla and other forage species for southern Australia. RIRDC Publication No $01 / 41$.

Fitouri SD, Trabelsi D, Saïdi S, Zribi K, Jeddi FB, Mhamdi R, 2012. Diversity of rhizobia nodulating sulla (Hedysarum coronarium L.) and selection of inoculant strains for semi-arid Tunisia. Ann. Microbiol. 62:77-84.

Fornara DA, Tilman D, 2008. Plant functional composition influences rates of soil carbon and nitrogen accumulation. J. Ecol. 96:314-22.

Frame J, 2005. Forage legumes for temperate grasslands. FAO, Rome, Italy.

Francaviglia R, Benedetti A, Doro L, Madrau S, Ledda L, 2014. Influence of land use on soil quality and stratification ratios under agro-silvo-pastoral Mediterranean management systems. Agric. Ecosyst. Environ. 183:86-92.

Gurfel D, Löbel R, Schiffmann J, 1982. Symbiotic nitrogen-fixing activity and yield potential of inoculated Hedysarum coronarium in Israel. Isr. J. Bot. 31:296-304.

Herridge D, Gemell G, Hartley E, 2002. Legume inoculants and quality control. ACIAR Proc. 109e:105-15.

Howieson JG, 1999. The host-rhizobia relationship. In: S.J. Bennett, P.S. Cocks (eds.) Genetic resources of Mediterranean pastures and forage legumes. Kluver Academic Publishers, Amsterdam, The Netherlands, pp. 96-106.

Huber S, Syed B, Freudenschuß A, Ernstsen V, Loveland P, 2001. Proposal for a European Soil Monitoring and Assessment Framework. European Environment Agency, Copenhagen, Denmark. Available from: https://www.eea.europa.eu/publications/Technical_report_No_61/at_download/file

Issolah R, Tahar A, Alane F, Sadi S, Adjabi M, Chellig-Siziani Y, Lebied M, 2014. Analysis of the Growth and the Chemical Composition within some Algerian Populations of Sulla. J. Biol. Sci. 14:220-5.

Lazzerini G, Migliorini P, Moschini V, Pacini C, Merante P, Vazzana C, 2014. A simplified method for the assessment of carbon balance in agriculture: an application in organic and conventional micro-agroecosystems in a long-term experiment in Tuscany, Italy. Ital. J. Agron. 9:55-62.

Liu WYY, Ridgway HJ, James TK, Premaratne M, Andrews M, 2012. Characterisation of rhizobia nodulating Galega officinalis (goat's rue) and Hedysarum coronarium (sulla). N. Z. Plant Prot. 65:192-6.

MacDuff JH, David SC, Davidson IA, 1996. Inhibition of $\mathrm{N}_{2}$ fixation by white clover (Trifolium repens L.) at low concentrations in $\mathrm{NO}_{-3}$ in flowing solution culture. Plant Soil. 180:287-95.

Molle G, Decandia M, Cabiddu A, Landau SY, 2008. An update on the nutrition of dairy sheep grazing Mediterranean pastures. Small Rumin. Res. 77:93-112.

Molle G, Decandia M, Fois N, Ligios S, Cabiddu A, Sitzia M, 2003. The performance of Mediterranean dairy sheep given access to sulla (Hedysarum coronarium L.) and annual ryegrass (Lolium rigidum Gaudin) pastures in different time proportions. Small Rumin. Res. 49:319-28.

Molle G, Decandia M, Giovanetti V, Cabiddu A, Fois N, Sitzia M, 2009. Responses to condensed tannins of flowering sulla (Hedysarum coronarium L.) grazed by dairy sheep: Part 1: Effects on feeding behaviour, intake, diet digestibility and performance. Livestock Sci. 123:138-46.

Muresu R, Sulas L, Polone E, Squartini A, 2005. PCR primers based on different portions of insertion elements can assist phylogeny studies, strain fingerprinting and species identification in rhizobia. FEMS Microbiol. Ecol. 54:445-53.

Namvar A, Sharifi R, Khandan T, Moghadam M, 2013. Seed Inoculation and Inorganic Nitrogen Fertilization Effects on Some Physiological and Agronomical Traits of Chickpea (Cicer arietinum L.) in Irrigated Condition. J. Cent. Eur. Agr. 14:28-40.

Naudin C, Corre-Hellou G, Pineau S, Crozat Y, Jeuffroy MH, 2010. The effect of various dynamics of $\mathrm{N}$ availability on winter pea-wheat intercrops: Crop growth, $\mathrm{N}$ partitioning and symbiotic N2 fixation. Field Crop Res. 119:2-11.

Omrane S, Chiurazzi M, 2009. A variety of regulatory mechanisms are involved in the nitrogen-dependent modulation of the nodule organogenesis program in legume roots. Plant Signal. Behav. 4:1066-8.

Piluzza G, Sulas L, Bullitta S, 2013. Tannins in forage plants and their role in animal husbandry and environmental sustainability: a review. Grass Forage Sci. 69:32-48.

Ramirez-Restrepo CA, Barry TN, 2005. Alternative temperate forages containing secondary compounds for improving sustainable productivity in grazing ruminants. Anim. Feed Sci. Technol. 120:179-201.

Razika G, Amira B, Yacine B, Ammar B, 2012. Influence of carbon source on the production of exopolysacharides by Rhizobium sullae and on the nodulation of Hedysarum coronarium L. legume. Afr. J. Microbio. Res. 6:5940-6.

Rochon JJ, Doyle CJ, Greef J, M, Hopkins A, Molle G, Sitzia M, Scholefield D, Smith CJ, 2004. Grazing legumes in Europe: A review of their status, management, benefits, research needs and future prospects. Grass Forage Sci. 59:197-214.

Rodriguez-Navarro DN, Temprano F, Orive R, 1991. Survival of Rhizobium sp. (Hedysarum coronarium L.) on peat-based inoculants and inoculated seeds. Soil Biol. Biochem. 23:375-9.

Ruisi P, Siragusa M, Di Giorgio G, Graziano D, Amato G, Carimi F, Giambalvo D, 2011. Pheno-morphological, agronomic and genetic diversity among natural populations of sulla (Hedysarum coronarium L.) collected in Sicily, Italy. Gen. Resour. Crop Evol. 58:245-57. 
Saia S, Urso V, Amato G, Frenda AS, Giambalvo D, Ruisi P, Di Miceli G, 2016. Mediterranean forage legumes grown alone or in mixture with annual ryegrass: biomass production, $\mathrm{N}_{2}$ fixation, and indices of intercrop efficiency. Plant Soil 402:395407.

SAS Software 1999. Version 9.02. SAS Institute Inc., Cary, NC, USA.

Seddaiu G, Porcu G, Ledda L, Roggero PP, Agnelli A, Corti G, 2013. Soil organic matter content and composition as influenced by soil management in a semi-arid Mediterranean agrosilvo-pastoral system. Agric. Ecosyst. Environ. 167:1-11.

Simon JC, Le Corre L, 1992. The apparent balance of nitrogen at the farm scale: methodology, examples of results. Fourrages. 129:79-94

Sinclair TR, Vadez V, 2012. The future of grain legumes in cropping systems. Crop Pasture Sci. 63:501-12.

Soil Survey Staff, 1999. Soil taxonomy: A basic system of soil classification for making and interpreting soil surveys. 2nd ed. USDA-NRCS Agric. Handb. 436. US Gov. Print. Office, Washington, DC, USA.

Sulas L, 2005. The future role of forage legumes in the Mediterranean climatic areas. In: S.G. Reynolds, J. Frame (eds.) Grasslands: developments opportunities perspectives. FAO, Rome, Italy, and Science Publishers, New Hampshire, USA, pp. 29-54.

Sulas L, Canu S, Ledda L, Carroni AM, Salis M, 2016. Yield and nitrogen fixation potential from white lupine grown in rainfed Mediterranean environments. Sci. Agric. 74:338-46.

Sulas L, Porqueddu C, Roggero PP, Bullitta P, 1995. The role and potential of sulla (Hedysarum coronarium L.) in the Mediterranean dairy sheep farming system. pp. 543-544 in Proc. 5th International Rangelands Congress, Salt Lake City, UT, USA.

Sulas L, Re GA, Ledda L, Caredda S, 1997. The effect of utilization frequency on the forage production of sulla (Hedysarum coronarium L.). Ital. J. Agron. 2:89-94.

Sulas L, Re, GA, Loi A, Howieson JG, 1998. The selection of optimal root-nodule bacteria inoculants increases the forage yield of Hedysarum coronarium (sulla). pp. 899-904, in Proc. 17th General Meeting of the European Grassland Federation; Debrecen, Hungary.

Sulas L, Roggero PP, Canu S, Seddaiu S, 2013. Potential nitrogen source from field bean (Vicia faba minor L.) under Mediterranean conditions. Agron. J. 105:1735-42.

Sulas L, Seddaiu G, Muresu R, Roggero PP, 2009. Nitrogen fixation of sulla under Mediterranean conditions. Agron. J. 101:1470-8.

Thami Alami I, El Mzouri EH, 2000. Study of the efficacy and persistence of Sulla rhizobium strains. Cah. Opt. Méditer. 45:321-5.
Unkovich M, Herridge D, Peoples M, Cadisch G, Boddey B, Giller $\mathrm{K}$, Alves B, Chalk P, 2008. Measuring plant-associated nitrogen fixation in agricultural systems. Australian Centre for International Agricultural Research, Canberra, Australia. Available from: http://aciar.gov.au/files/node/10169/mn136 measuring_plant_associated_nitrogen_fixation_19979.pdf

Van Kessel C, Hartley C, 2000. Agricultural management of grain legumes: has it led to an increase in nitrogen fixation? Field Crop, Res. 65:165-81.

Vendramin E, Velazquez E, Mateos PF, Martinez-Molina E, Dazzo FB, Casella S, Nuti MP, 2002. Rhizobium sullae sp. nov. (Formerly Rhizobium "hedysari"): The microsymbiont of Hedysarum coronarium L. Int. J. Syst. Evol. Microbiol. 52: 1267-76.

Voisin AS, Salon C Munier-Jolain NG, Ney B, 2002. Quantitative effects of soil nitrate, growth potential and phenology on symbiotic nitrogen fixation of pea (Pisum sativum L.). Plant Soil. 243:31-42.

Warembourg FR, 1993. Nitrogen fixation in soil and plant systems, in: Knowles R and Blackburn TH (eds.), Nitrogen Isotope Techniques, Academic Press, New York, NY, USA, pp 127156.

Waterer JG, Vessey JK, 1993. Effect of low static nitrate concentrations on mineral nitrogen uptake nodulation, and nitrogen fixation in field pea. J. Plant Nutr. 16:1775-89.

Woodward SL, Waghorn GC, Lassey KR, Laboyrie PG, 2002. Does feeding sulla (Hedysarum coronarium) reduce methane emissions from dairy cows? Proc. N.Z. Soc. Anim. Prod. 66:227-30.

Yates R, Foster K, Nichols PGH, Ewing MA, 2006. 'Flamenco' A new variety of sulla for southern Australia. Proc. of the 13th Australian Agronomy Conference, Perth. Available from: http://www.regional.org.au/au/asa/2006/poster/systems/4842 yatesr.htm

Yates R, Howieson J, De Meyer SE, Tian R, Seshadri R, Pati A, Woyke T, Markowitz V, Ivanova N, Kyrpides N, Loi A, Nutt B, Garau G, Sulas L, Reeve W, 2015. High-quality permanent draft genome sequence of Rhizobium sullae strain WSM1592; a Hedysarum coronarium microsymbiont from Sassari, Italy. Stand. Genomic Sci. 10:44.

Yates R, Howieson JH, Revell C, 2010. Inoculating pasture legumes. Farmnote no. 431/2010, Department of Agriculture and Food of Western Australia, University of Perth, Australia.

Yates RJ, Howienson JG, Carr SJ, 1996. The role of root-nodule bacteria in the adaptation of two long lived forage legumes from the Mediterranean basin to Western Australia. Proc. 11th $\mathrm{N}$-fixation Conference; 1996; University of Western Australia. pp. 144-5. 